\title{
UJI ABB INDEKS STABILITAS TOTAL-TOTAL DALAM PENERAPAN BAHAN PREDIKTOR KEJADIAN CUMULONIMBUS DAN THUNDERSTORM DI PANGKALPINANG
}

\author{
Fadel Muhammad Madjid $^{1, \text { a) }}$, Antika Heni Hestiwi ${ }^{1, b)}$, Putri Santy Siregar ${ }^{1, c)}$ \\ ${ }^{1}$ Sekolah Tinggi Meteorologi Kliamtologi dan Geofisika, Jl Perhubungan 1 No 5Komplek Meteorologi, Pondok \\ betung, Pondok Aren, Tangerang Selatan 15221 \\ Email: a)madjid.fm96@gmail.com, b)antikahaha@gmail.com, c)putrisantyyy@gmail.com
}

\begin{abstract}
Abstrak
Kondisi stabilitas atmosfer sangat diperhitungkan dalam prakiraan cuaca khususnya prakiraan cuaca jangka pendek. Indeks stabilitas dapat dijadikan sebagai acuan untuk menentukan kondisi cuaca ke depan untuk melihat potensi konvektivitas awan Cumulonimbus (CB) dan potensi kejadian Thunderstorm (TS). Namun, ambang batas lama (ABL) dari indeks stabilitas masih dianggap belum cocok untuk kondisi di daerah Pangkalpinang. Penelitian ini menggunakan indeks stabilitas Total-Total jam 00 \& 12 UTC bulan Januari hingga Desember tahun 2012-2015 sebagai bahan pembuatan ambang batas baru (ABB) dengan menggunakan perhitungan statistik. Setelah ABB telah diperoleh, maka dilakukan uji performa pada bulan Januari hingga Desember tahun 2016. Kejadian CB dan TS sudah dapat terjadi pada TT $\geq 37,76$. Berdasarkan tabel kontingensi, kejadian 'miss' yang terdapat pada ABB lebih sedikit daripada ABL. Probabilitas kejadian CB \& TS yang dapat dideteksi oleh ABB jauh lebih besar daripada ABL. Akurasi ABB lebih baik pada siang hari daripada malam hari. Karena itu ABB dapat dikatakan mampu meningkatkan sensitivitas dalam mendeteksi kejadian CB dan TS.
\end{abstract}

Kata-kata kunci: Total-Total, ambang batas, CB, TS

\begin{abstract}
Atmospheric stability condition is needed to be noticed in a weather forecast especially for short range forecasting. Stability index can be used as a reference to determine future conditions about the exitence of thunderstorm and Cumulonimbus clouds. But the old Total-Totals (TT) threshold is still considered unsuitable for Pangkalpinang. This study uses Total-Totals Index from January to December at 20122015 to get the recent Total-Totals (TT) threshold using statistic calculation. After the recent TotalTotals (TT) threshold was obtained, performance test is done for Januari to December 2016. Thunderstorm could already happen when the Total Totals(TT) Index is TT $\geq 37,76$. Based on contingency tabel, 'miss' condition on recent Total-Totals (TT) threshold less than the old Total-Totals (TT) threshold . In reverse with the 'hit' condition. Probability of Cb and TS that could be detected by recent Total-Totals (TT) threshold is better than the old Total-Totals (TT) threshold. The accuration of recent Total-Totals (TT) threshold is better during the day than during the night. It can be concluded that recent Total-Totals (TT) threshold is able to improve sensitivity on detecting existence of CB and TS.
\end{abstract}

Keywords: Total-Totals, Threshold, CB, TS 


\section{PENDAHULUAN}

Awan Cumulonimbus merupakan salah satu indikasi awal dari berbagai fenomena cuaca buruk yang perlu diperhatikan keberadaannya karena dapat menimbulkan bahaya bagi beberapa sektor kehidupan manusia. Awan Cumulonimbus memiliki ciri-ciri tebal, gelap, dan bergelombang yang bisa tumbuh sangat tinggi dimana bagian puncak awan merupakan bongkahan es dan puncak awan akan memiliki bentuk menyerupai landasan [1]. Awan Cumulonimbus dapat menimbulkan salah satu fenomena cuaca buruk yaitu thunderstorm, tetapi tidak selalu keberadaan awan Cumulonimbus diikuti oleh kejadian thunderstorm.

Thunderstorm merupakan fenomena kelistrikan udara berupa pelepasan muatan listrik yang terjadi di udara karena adanya perbedaan medan listrik antara dua massa dengan muatan listrik yang berbeda untuk mencapai kesetimbangan [2]. Thunderstorm dihasilkan oleh awan Cumulonimbus baik dalam single cell, super cell maupun multi cell. Thunderstorm terjadi karena adanya perbedaan potensial antara awan dan bumi atau awan dengan awan lainnya atau terjadi di dalam awan itu sendiri.

Prediksi keberadaan awan Cumulonimbus dan thunderstorm sangat diperlukan mengingat keberadaannya sering diikuti dengan cuaca buruk seperti turbulensi, angin kencang, hujan deras secara tiba-tiba dan sebagainya. Salah satu metode untuk acuan membuat prediksi awan Cumulonimbus dan thunderstorm adalah dengan memanfaatkan data sounding khususnya indeks Total-Totals (TT). Indeks Total-Totals adalah indeks stabilitas atmosfer dengan menjumlahkan indeks Vertical Totals (VT) dan indeks Cross Totals (CT) [3] yang dirumuskan sebagai berikut :

$\mathrm{TT}=\mathrm{VT}+\mathrm{CT}$, dimana

$\mathrm{VT}=\mathrm{T}_{850}-\mathrm{T}_{500}$ dan $\mathrm{CT}=\mathrm{D}_{850}-\mathrm{T}_{500}$

$\mathrm{TT}=\mathrm{T}_{850}+\mathrm{D}_{850}-2 \mathrm{~T}_{500}$

Pada penelitian sebelumnya telah ditentukan ambang batas untuk menunjukkan potensi kejadian thunderstorm [4]. Namun nilai ambang batas tersebut adalah hasil penelitian yang dilakukan di daerah lintang tinggi yang karakteristik atmosfernya berbeda dengan Indonesia yang berada di lintang rendah. Oleh sebab itu, perlu dikaji ulang nilai ambang batas baru (ABB) indeks Total-Totals (TT) terkait pembentukan awan Cumulonimbus dan thunderstorm yang sesuai untuk wilayah lintang rendah, khususnya Pangkalpinang.

\section{METODELOGI PENELITIAN}

Metode yang digunakan dalam penelitian ini adalah sebagai berikut:

1. Mengelompokkan indeks stabilitas pada data pengamatan udara atas berdasarkan waktu kejadian tersebut. Indeks stablitas Total-total pada jam 0 UTC digunakan untuk memverifikasi kondisi cuaca 12 jam ke depan, demikian pula indeks stabilitas Total-total pada jam 12 UTC digunakan untuk memverifikasi kondisi cuaca 12 jam ke depan.

2. Mengelompokkan kejadian awan Cumulonimbus dan thunderstorm disesuaikan dengan jam indeks stabilitas yang ditentukan.

3. Menentukan ambang batas baru sesuai dengan persamaan Sturges yaitu [5]:

$$
\begin{aligned}
& k=1+3,322 \log n \\
& r=X_{n}-X_{i} \\
& \text { interval }=\frac{r}{k}
\end{aligned}
$$

4. Melakukan perbandingan antara ambang batas lama dan ambang batas baru terhadap kejadian awan Cumulonimbus dan thunderstorm.

5. Melakukan uji performa terhadap ambang batas lama dan ambang batas baru berdasarkan tabel kontingensi 2x2 dibawah ini [6]. 
TABEL 1. Tabel kontingensi 2x2

\begin{tabular}{|c|c|c|c|c|}
\hline & \multicolumn{3}{|c|}{ OBSERVASI } \\
\hline & & Yes & No & TOTAL \\
\hline \multirow{3}{*}{ 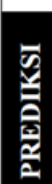 } & Yes & Hits & False Alarms & Forecast Yes \\
\hline & No & Misses & Correct Negatives & Forecast No \\
\hline & TOTAL & Observed Yes & Observed No & TOTAL \\
\hline
\end{tabular}

Uji performa dilakukan untuk menentukan tingkat akurasi dengan menghitung bias, POD, akurasi, Threat Score dan HSS berdasarkan pada perhitungan sebagai berikut:

$$
\begin{aligned}
& \text { Bias }=\frac{\text { Hits }+ \text { False Alarms }}{\text { Hits }+ \text { Misses }} \\
& P O D=\frac{\text { Hits }}{\text { Hitg }+ \text { Migseg }} \\
& \text { Akurasi }=\frac{\text { Hits }+ \text { Correct Negatives }}{\text { Total }} \\
& \text { Threat Score }=\frac{\text { Hits }}{\text { Hits }+ \text { False Alarms + Misses }} \\
& F A R=\frac{\text { False Alarms }}{\text { Hitg }+ \text { False Alarms }} \\
& \text { HSS }=\frac{2(\text { Hitsx CN }- \text { FAxMisses })}{(\text { Hits }+ \text { Misses })(\text { Misses }+C \mathrm{CN})+(\text { Hits }+ \text { FA })(\text { RA }+\mathrm{CN})}
\end{aligned}
$$

Penggunaan bias bertujuan untuk mengetahui sifat dari indeks apakah overforecast atau underforecast. POD merupakan probabilitas indeks yang dapat memprediksi kejadian Cumulonimbus dan thunderstorm. Akurasi merupakan jumlah kebenaran secara keseluruhan. Threatscore menunjukkan skill prediksi pada suatu indeks. FAR merupakan jumlah prediksi yang menunjukkan kejadian ya namun tidak terjadi. HSS menunjukkan Jumlah relatif terhadap kejadian acak.

6. Melakukan perbandingan performa antara ambang batas lama dengan ambang batas baru.

\section{HASIL DAN PEMBAHASAN}

\section{Perbandingan antara ABB dan ABL}

TABEL 2. Perbandingan ABL dan ABB tahun 2011-2015

\begin{tabular}{llll}
\hline ABL & Jumlah & ABB & Jumlah \\
\hline$<44$ & 1858 & $<37.76$ & 1003 \\
$44-55$ & 895 & $37.76-42.04$ & 1590 \\
$>55$ & 1 & $42.04-46.32$ & 157 \\
& & $46.32-50.6$ & 3 \\
& & $>50.6$ & 1 \\
Total & 2754 & Total & 2754 \\
\hline
\end{tabular}

Pembagian kelas dalam ABL terbagi menjadi 3 kelas [4]. Indeks $<44$ menunjukkan tidak akan terjadi thunderstorm. Indeks 44-55 menunjukkan akan terjadi thunderstorm, serta indeks $>55$ menunjukkan akan terjadi thunderstorm hebat.

Menurut penelitian yang telah dilakukan dengan melakukan beberapa modifikasi, maka didapatkan ABB indeks TT memiliki 5 kelas dengan interval data 4,28. Kelas terbawah menunjukkan indeks TT $<37.76$ menunjukkan tidak akan terjadi Cumulonimbus dan/atau thunderstorm. Selain kelas tersebut maka diasumsikan bahwa kejadian Cumulonimbus dan/atau thunderstorm akan terjadi. Asumsi tersebut digunakan untuk membedakan antara kejadian awan Cumulonimbus atau tidak dan/atau kejadian thunderstorm atau tidak. 
Jumlah data pada indeks TT ABL < 44, 44-55, >55 pada tahun 2012-2015 memiliki jumlah data berturut-turut sebanyak 1858, 895 dan 1 . Sementara jumlah data pada indeks TT ABB <37.76, 37.7642.04, 42.04-46.32, 46.32-50.6, 50.6 pada tahun 2012-2015 memiliki jumlah data berturut-turut sebanyak 1003, 1590, 157, 3 dan 1. Distribusi data yang didapat pada ABL menunjukkan bahwa jumlah data terkonsentrasi pada indeks $<44$, sementara pada ABB modus terletak pada interval 37.76-42.04.

\section{Verifikasi ABL dan ABB untuk tahun 2016}

TABEL 3. Verifikasi ABL pada tahun 2016

\begin{tabular}{llllll}
\hline \multirow{2}{*}{ ABL } & $\begin{array}{l}\text { Jumlah } \\
\text { indeks }\end{array}$ & $\begin{array}{l}\text { Jumlah } \\
\text { CB Siang }\end{array}$ & $\begin{array}{l}\text { Jumlah } \\
\text { CB Malam }\end{array}$ & $\begin{array}{l}\text { Jumlah TS } \\
\text { Siang }\end{array}$ & $\begin{array}{l}\text { Jumlah TS } \\
\text { Malam }\end{array}$ \\
\hline$<44$ & 491 & 185 & 112 & 71 & 35 \\
$44-55$ & 227 & 104 & 49 & 38 & 22 \\
$>55$ & 0 & 0 & 0 & 0 & 0 \\
Total & 718 & 289 & 161 & 109 & 57 \\
\hline
\end{tabular}

TABEL 4. Verifikasi ABL pada tahun 2016

\begin{tabular}{llllll}
\hline \multirow{2}{*}{ ABB } & $\begin{array}{l}\text { Jumlah } \\
\text { indeks }\end{array}$ & $\begin{array}{l}\text { Jumlah } \\
\text { CB Siang }\end{array}$ & $\begin{array}{l}\text { Jumlah } \\
\text { CB Malam }\end{array}$ & $\begin{array}{l}\text { Jumlah } \\
\text { TS Siang }\end{array}$ & $\begin{array}{l}\text { Jumlah TS } \\
\text { Malam }\end{array}$ \\
\hline$<37.76$ & 23 & 10 & 3 & 1 & 1 \\
$37.76-42.04$ & 193 & 70 & 40 & 22 & 12 \\
$42.04-46.32$ & 475 & 196 & 116 & 84 & 44 \\
$46.32-50.6$ & 26 & 12 & 2 & 2 & 0 \\
$>50.6$ & 1 & 1 & 0 & 0 & 0 \\
Total & 718 & 289 & 161 & 109 & 57 \\
\hline
\end{tabular}

Verifikasi ABL dilakukan pada tahun berikutnya yaitu 2016 dengan membagi kejadian Cumulonimbus dan thunderstorm menjadi 2 waktu. Pada tabel 3 dan 4 dapat dijelaskan bahwa jumlah kejadian Cumulonimbus maupun thunderstorm pada malam hari lebih sedikit daripada siang hari. Selain itu, jumlah kejadian Cumulonimbus lebih banyak daripada jumlah kejadian thunderstorm.

Dalam ABL jumlah kejadian Cumulonimbus maupun thunderstorm sangat besar pada indeks $<44$. Sementara menurut Alford [4], pada indeks $<44$ seharusnya tidak akan terjadi thunderstorm. Hal ini membuktikan bahwa ABL masih belum cocok jika diterapkan untuk prediktor Cumulonimbus dan thunderstorm di daerah Pangkalpinang.

Penerapan ABB untuk prediktor Cumulonimbus dan thunderstorm pada tahun 2016 menunjukkan indeks $<37.76$ memiliki jumlah kejadian Cumulonimbus dan thunderstorm yang lebih sedikit daripada indeks di ABL. Jumlah meningkat pada indeks-indeks yang lebih besar, lalu menurun pada indeks yang sangat besar. Hal ini dikarenakan indeks yang sangat besar sangat jarang terjadi.

\section{Perbandingan performa ABL dan ABB}

TABEL 5. Performa ABL dan ABB terhadap kejadian Cumulonimbus pada siang hari

\begin{tabular}{lllllllllllll}
\hline Bulan ke & 1 & 2 & 3 & 4 & 5 & 6 & 7 & 8 & 9 & 10 & 11 & 12 \\
\hline POD ABL (\%) & 36 & 24 & 56 & 54 & 24 & 38 & 42 & 40 & 17 & 26 & 25 & 53 \\
POD ABB (\%) & 100 & 100 & 100 & 100 & 100 & 95 & 88 & 95 & 87 & 91 & 100 & 100 \\
TSc ABL (\%) & 32 & 23 & 52 & 54 & 24 & 38 & 41 & 36 & 15 & 23 & 24 & 38 \\
TSc ABB (\%) & 90 & 93 & 90 & 93 & 94 & 69 & 79 & 61 & 69 & 70 & 83 & 50 \\
FAR ABL (\%) & 23 & 14 & 12 & 0 & 0 & 0 & 8 & 20 & 50 & 33 & 14 & 43 \\
FAR ABB (\%) & 10 & 7 & 10 & 7 & 6 & 29 & 12 & 37 & 23 & 25 & 17 & 50 \\
Akurasi ABL (\%) & 32 & 26 & 55 & 57 & 29 & 57 & 45 & 55 & 23 & 35 & 34 & 57 \\
Akurasi ABB (\%) & 90 & 93 & 87 & 93 & 94 & 73 & 90 & 65 & 77 & 74 & 83 & 50 \\
Bias ABL & 0,5 & 0,3 & 0,6 & 0,5 & 0,2 & 0,4 & 0,5 & 0,5 & 0,3 & 0,4 & 0,9 & 0,9 \\
Bias ABB & 1,1 & 1,1 & 1,1 & 1,1 & 1,1 & 1,3 & 1 & 1,5 & 1,1 & 1,2 & 1,2 & 2 \\
HSS ABL & $-0,2$ &,- 1 & 0 & 0,1 & 0 & 0,3 & 0 & 0,2 & $-0,2$ & $-0,1$ & 0 & 0,1 \\
HSS ABB & 0 & 0 & 0,4 & 0 & 0 & 0,1 & $-0,1$ & $-0,1$ & 0 & 0 & 0 & 0 \\
\hline
\end{tabular}


TABEL 6. Performa ABL dan ABB terhadap kejadian Cumulonimbus pada malam hari

\begin{tabular}{lllllllllllll}
\hline Bulan ke & 1 & 2 & 3 & 4 & 5 & 6 & 7 & 8 & 9 & 10 & 11 & 12 \\
\hline POD ABL (\%) & 50 & 38 & 56 & 24 & 25 & 30 & 14 & 33 & 40 & 27 & 0 & 18 \\
POD ABB (\%) & 100 & 92 & 100 & 100 & 100 & 96 & 100 & 100 & 100 & 100 & 90 & 100 \\
TSc ABL (\%) & 29 & 31 & 43 & 17 & 24 & 29 & 7 & 23 & 29 & 18 & 0 & 15 \\
TSc ABB (\%) & 32 & 43 & 55 & 57 & 65 & 87 & 24 & 33 & 36 & 37 & 32 & 35 \\
FAR ABL (\%) & 53 & 38 & 36 & 64 & 17 & 11 & 89 & 57 & 50 & 67 & 100 & 50 \\
FAR ABB (\%) & 68 & 56 & 45 & 43 & 35 & 10 & 76 & 67 & 64 & 63 & 67 & 65 \\
Akurasi ABL (\%) & 61 & 61 & 61 & 33 & 48 & 33 & 53 & 64 & 64 & 55 & 55 & 65 \\
Akurasi ABB (\%) & 32 & 46 & 61 & 57 & 65 & 90 & 23 & 32 & 36 & 35 & 34 & 55 \\
Bias ABL & 1,2 & 0,6 & 0,9 & 0,6 & 0,3 & 0,3 & 1,3 & 0,8 & 0,8 & 0,8 & 0,3 & 0,4 \\
Bias ABB & 3,1 & 2,1 & 1,8 & 1,8 & 1,6 & 1,1 & 4,1 & 3 & 2,8 & 2,7 & 2,7 & 2,8 \\
HSS ABL & 0,2 & 0,2 & 0,2 & $-0,3$ & 0,1 & 0 & $-0,2$ & 0,1 & 0,2 & 0 & $-0,2$ & 0,1 \\
HSS ABB & 0 & $-0,1$ & 0,1 & 0,1 & 0 & 0 & $-0,1$ & 0 & 0 & 0 & 0 & 0 \\
\hline
\end{tabular}

TABEL 7. Performa ABL dan ABB terhadap kejadian thunderstorm pada siang hari

\begin{tabular}{lllllllllllll} 
Bulan ke & 1 & 2 & 3 & 4 & 5 & 6 & 7 & 8 & 9 & 10 & 11 & 12 \\
\hline POD ABL (\%) & 22 & 40 & 63 & 44 & 25 & 50 & 60 & 40 & 20 & 22 & 17 & 57 \\
POD ABB (\%) & 100 & 100 & 100 & 100 & 100 & 83 & 100 & 100 & 100 & 100 & 100 & 100 \\
TSc ABL (\%) & 10 & 20 & 25 & 29 & 19 & 27 & 21 & 15 & 15 & 13 & 12 & 24 \\
TSc ABB (\%) & 29 & 19 & 27 & 53 & 39 & 17 & 19 & 17 & 58 & 32 & 41 & 23 \\
FAR ABL (\%) & 85 & 71 & 71 & 53 & 57 & 63 & 75 & 80 & 63 & 78 & 71 & 71 \\
FAR ABB (\%) & 71 & 81 & 73 & 47 & 61 & 82 & 81 & 83 & 42 & 68 & 59 & 77 \\
Akurasi ABL (\%) & 42 & 70 & 52 & 43 & 58 & 73 & 62 & 65 & 43 & 55 & 48 & 57 \\
Akurasi ABB (\%) & 29 & 19 & 26 & 53 & 39 & 23 & 17 & 16 & 50 & 35 & 41 & 23 \\
Bias ABL & 1,4 & 1,4 & 2,1 & 0,9 & 0,6 & 1,3 & 2,4 & 2 & 0,5 & 1 & 0,6 & 2 \\
Bias ABB & 3,4 & 5,4 & 3,8 & 1,9 & 2,6 & 4,7 & 5,2 & 6 & 1,7 & 3,1 & 2,4 & 4,3 \\
HSS ABL & $-0,2$ & 0,1 & 0,1 & $-0,1$ & 0 & 0,3 & 0,1 & 0,1 & $-0,1$ & $-0,1$ & $-0,1$ & 0,1 \\
HSS ABB & 0 & 0 & 0 & 0 & 0 & $-0,1$ & 0 & 0 & 0,3 & 0,1 & 0 & 0 \\
\hline
\end{tabular}

TABEL 8. Performa ABL dan ABB terhadap kejadian thunderstorm pada malam hari

\begin{tabular}{lllllllllllll}
\hline Bulan ke & 1 & 2 & 3 & 4 & 5 & 6 & 7 & 8 & 9 & 10 & 11 & 12 \\
\hline POD ABL (\%) & 67 & 60 & 67 & 25 & 36 & 56 & 0 & 67 & 0 & 33 & 0 & 50 \\
POD ABB (\%) & 100 & 100 & 100 & 100 & 100 & 100 & 100 & 100 & 100 & 100 & 83 & 100 \\
TSc ABL (\%) & 15 & 30 & 13 & 12 & 31 & 38 & 0 & 25 & 0 & 9 & 0 & 20 \\
TSc ABB (\%) & 10 & 19 & 10 & 27 & 35 & 31 & 7 & 11 & 7 & 10 & 18 & 6 \\
FAR ABL (\%) & 83 & 63 & 86 & 82 & 33 & 44 & 100 & 71 & 100 & 89 & 100 & 75 \\
FAR ABB (\%) & 90 & 81 & 90 & 73 & 65 & 69 & 93 & 89 & 93 & 90 & 81 & 94 \\
Akurasi ABL (\%) & 65 & 75 & 61 & 50 & 71 & 73 & 63 & 79 & 64 & 68 & 69 & 87 \\
Akurasi ABB (\%) & 10 & 18 & 16 & 27 & 35 & 30 & 7 & 11 & 7 & 10 & 21 & 6 \\
Bias ABL & 4 & 1,6 & 4,7 & 1,4 & 0,5 & 1 & 4,5 & 2,3 & 4 & 3 & 0,5 & 2 \\
Bias ABB & 10 & 5,4 & 9,7 & 3,8 & 2,8 & 3,2 & 14 & 9 & 14 & 10 & 4,5 & 15 \\
HSS ABL & 0,1 & 0,3 & 0,1 & $-0,1$ & 0,3 & 0,4 & $-0,1$ & 0,3 & $-0,1$ & 0 & $-0,2$ & 0,3 \\
HSS ABB & 0 & 0 & 0 & 0 & 0 & 0 & 0 & 0 & 0 & 0 & $-0,1$ & 0 \\
\hline
\end{tabular}

Jika ditinjau dari POD pada ABB kejadian Cumulonimbus dan/atau thunderstorm baik pada siang maupun malam jauh lebih bagus ketimbang ABL. POD pada ABB memiliki rentang 83-100 \%, sementara ABL memiliki rentang lebih rendah yaitu 0-67\%. Hal ini dikarenakan hits pada ABB lebih banyak daripada ABL, sementara miss lebih sedikit ketimbang pada ABL. Jadi, dapat dikatakan bahwa kemampuan ABB untuk mendeteksi Cumulonimbus dan/atau thunderstorm di pagi dan malam jauh lebih bagus daripada ABL.

Threat Score untuk meprediksi kejadian Cumulonimbus pada ABB jauh lebih bagus daripada ABL. Threat Score pada ABB memiliki rentang 50 - $94 \%$ untuk siang hari dan rentang $24-87 \%$ untuk malam hari. Pada ABL, Threat Score memiliki rentang 15 hingga $54 \%$ untuk sang hari dan rentang $0-43 \%$. Nilai pada Threat Score pada ABL membuktikan skill prediksi kejadian Cumulonimbus masih kurang cocok, begitu sebaliknya dengan ABB. 
Skill prediksi kejadian thunderstorm pada ABB memiliki rentang 17 - $58 \%$ pada siang hari dan rentang 6 - $35 \%$ pada malam hari. Sementara skill prediksi pada ABL memiliki rentang $10-27 \%$ pada siang hari dan rentang $0-38 \%$ pada malam hari. Nilai Threat Score pada ABB lebih bagus daripada ABL, namun untuk malam hari baik ABB maupun ABL memiliki nilai yang kurang bagus.

Kejadian thunderstorm pada malam hari sangat sedikit sehingga hits akan sedikit sementara false alarm akan banyak. Hal ini ditunjukkan oleh False Alarm Ratio (FAR) untuk kejadian Cumulonimbus ataupun thunderstorm pada malam hari yang sangat besar baik ABB maupun ABL. Nilai FAR yang tinggi dalam prediksi kejadian ekstrim seperti thunderstorm merupakan hal yang biasa karena kejadian ekstrim memang jarang terjadi [6]. Jika FAR memiliki nilai sebesar $100 \%$ maka dapat dikatakan bahwa indeks tersebut tidak dapat menangkap kejadian Cumulonimbus ataupun thunderstorm seperti pada ABL bulan Juli, September dan November.

Namun, FAR pada siang hari baik pada ABL maupun ABB menunjukkan angka yang cukup baik daripada malam hari. Nilai FAR pada ABL memiliki rentang $0-50 \%$ sementara ABB memiliki rentang $7-50 \%$. Nilai FAR memiliki nilai $0 \%$ menunjukkan bahwa false alarm pada ABL tidak ada karena sifatnya yang lebih underforecast ketimbang ABB. Imbas dari sifat underforecast tersebut kemampuan false alarmnya sangat sedikit, sementara ABB sebaliknya.

Sifat under maupun overforecast dapat ditunjukkan oleh nilai bias masing-masing ambang batas. Rentang nilai bias ABL pada prediksi Cumulonimbus pada siang hari dan malam hari berturut-turut adalah 0,2 - 0,9 dan 0,3-1,3. Lalu rentang nilai bias ABB pada prediksi Cumulonimbus pada siang hari dan malam hari berturut -turut adalah $1-2$ dan 1,1-4,1. Kemudian nilai bias ABL pada prediksi thunderstorm pada siang hari dan malam hari adalah $0,5-2,4$. Sementara nilai bias ABB pada prediksi thunderstorm pada siang hari dan malam hari adalah 1,7 - 6 dan 2,8 - 15,5.

Dalam nilai bias dapat didefinisikan bahwa sifat dari ABL lebih underforecast dari ABB karena nilainya yang selalu berada dibawah ABB setiap bulan. Sifat sangat underforecast dapat ditunjukkan oleh ABB prediktor Cumulonimbus siang hari, sementara sifat sangat overforecast ditunjukkan oleh ABB prediktor thunderstorm malam hari. Jadi dapat dikatakan bahwa kedua ambang batas memiliki sifat yang saling berlawanan.

Nilai underforecast pada ABL disebabkan karena kemampuan hits-nya yang sedikit diikuti dengan kemampuan miss-nya yang banyak. Secara definitif, kemampuan ABL kurang bagus dalam menangkap kejadian Cumulonimbus maupun thunderstorm karena terlalu banyak miss. Lain kata dengan overforecast pada ABB karena kemampuan hits dan false alarmnya yang banyak sementara nilai missnya sedikit. Jadi kemampuan ABB dalam menangkap kejadian Cumulonimbus dan thunderstorm bagus, tetapi sering memberikan prediksi ya untuk ketidakjadian Cumulonimbus maupun thunderstorm.

Lalu menurut pengujian kebenaran total yaitu akurasi ABL dan ABB baik pada siang maupun malam menunjukkan hasil yang sangat bervariasi. ABB pada siang hari cenderung lebih bagus daripada ABL, namun pada malam hari justru ABL lebih bagus daripada ABB. Secara keseluruhan rentang nilai akurasi $\mathrm{ABL}$ dan $\mathrm{ABB}$ berturut-turut sebesar $23-87 \%$ dan 6 -94\%.

Akan tetapi, akurasi bagus pada ABL malam hari mendapat sumbangan dari jumlah Correct Negative dari setiap ketidakjadian Cumulonimbus maupun thunderstorm. Ini adalah imbas dari aktivitas konveksi yang cenderung lebih bagus pada siang/sore hari [7]. Oleh sebab itu, kemampuan ABL sangat baik untuk memprediksi ketidakjadian Cumulonimbus maupun thunderstorm. Hal ini dapat dilihat pada bulan dengan kejadian Cumulonimbus maupun thunderstorm yang rendah pada bulan Juli, Agustus dan September.

Nilai HSS menunjukkan skill prakiraan terhadap kejadian acak untuk 12 jam ke depan pada tiap ambang batas. Baik pada ABL maupun ABB menunjukkan skill yang cukup bagus dengan rentang 0,3 - 0,4 dan -0,1 - 0,3. Jika dibandingkan secara mendetail, maka ABL lebih bagus pada prediksi thunderstorm pada malam hari sementara ABB bagus untuk memprediksi kejadian Cumulonimbus dan thunderstorm pada siang hari. Akan tetapi, secara keseluruhan ABB lebih bagus daripada ABL untuk diterapkan. 


\section{SIMPULAN}

Berdasarkan pembahasan diatas dapat disimpulkan bahwa kejadian Cumulonimbus maupun thunderstorm sudah dapat terjadi pada nilai TT > 37,76. Kemampuan prediksi ABB untuk mendeteksi kejadian Cumulonimbus atau thunderstorm sangat bagus ketimbang ABL. Sifat ABB lebih overforecast daripada ABL yang menyebabkan nilai FAR sangat tinggi namun itu hal biasa karena kejadian thunderstorm merupakan kejadian ekstrim yang jarang terjadi.

Akan tetapi, pada penelitian ini penulis menyarankan dalam memprediksi kejadian Cumulonimbus dan thunderstorm diperlukan indeks lain seperti SWEAT, CAPE dan CIN. Selain itu, ambang batas akan lebih bagus jika digunakan data klimatologis pengamatan udara atas dengan rentang waktu minimal 30 tahun.

\section{UCAPAN TERIMAKASIH}

Penulis mengucapkan terimakasih kepada Stasiun Meteorologi Pangkalpinang yang telah memberikan data observasi. Oleh sebab itu, penulis dapat menyelesaikan penelitian sesuai dengan harapan.

\section{REFERENSI}

[1] Lutgens, F., K., Taaarbbbuck, E., 2010, The Atttmosphere: an Introduction to Meteorology 11th edition, Pearson, America.

[2] Griffiths, D., J., 1995, Introduction to Electrodynamics, 2nd edition, Prentice Hall of India Private Limited.

[3] Miller, Robert C., 1972, Notes On Analysisi And Savere Storm Forecasting Procedures of The Air Forece Global Weather Central, Air Weather Service (MAC) United States Air Force.

[4] Budiarti, Maria., dkk, 2012, Studi Indeks Stabilitas Udara Terhadap Prediksi Kejadian Badai Guntur (Thunderstorm) di Wilayah Stasiun cengkareng Banten, Jurnal Meteorologi dan Geofisika Vol. 13 No 2 Tahun 2012 : 111-117.

[5] Sturges, H., 1926, The Choice of a Class - Interval, J. Amer Statist. Assoc., 21, 6566.

[6] Gustari, I., Hadi, T., W., Hadi, S., Renggono, F., 2012, Akurasi Prediksi Curah Hujan Operasional Di Jabodetabek: Perbandingan Dengan Model WRF, BMKG, Jakarta.

[7] Tjasjono, H.K., 2007, Meteorologi Terapan, ITB, Bandung. 
